\title{
$\mathrm{CPV}$ 모듈의 2차 광학계 특성에 따른 성능분석
}

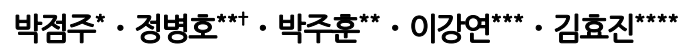

*한국알루미늄시험연구원

**남부대학교 전기공학과, 교수

***조선이공대학교 전기과, 교수

****한국광기술원, 책임연구원

\section{Performance Analysis of CPV Modules for Optimizing Secondary Optical Elements}

\author{
Park Jeom-Ju* $\cdot$ Jeong Byeong-Ho ${ }^{* \star+} \cdot$ Park Ju-Hoon ${ }^{* \star} \cdot$ Lee Kang-Yeon $^{\star \star *} \cdot$ Kim Hyo-Jin ${ }^{\star \star * *}$ \\ *Principal, Korea Aluminium Laboratories \\ ${ }^{* *}$ Professor, Department of Electrical Engineering, Nambu University \\ ${ }^{* * *}$ Professor, Department of Electrical Engineering, Chosun College of Science \& Technology \\ ${ }^{* * * *}$ Senior Researcher, Koreae Photonics Technology Institute \\ ${ }^{\dagger}$ Corresponding author: energy@nambu.ac.kr
}

\section{OPEN ACCESS (c) (1) (\$)}

Journal of the Korean Solar Energy Society Vol.40, No.5, pp.23-34, October 2020 https://doi.org/10.7836/kses.2020.40.5.023

pISSN : 1598-6411

elSSN : 2508-3562

Received: 10 July 2020

Revised: 01 October 2020

Accepted: 06 October 2020

Copyright (C) Korean Solar Energy Society

This is an Open-Access article distributed under the terms of the Creative Commons Attribution NonCommercial License which permits unrestricted non-commercial use, distribution, and reproduction in any medium, provided the original work is properly cited.

\begin{abstract}
Concentrator photovoltaic (CPV) system consists of high-quality complex optical elements, mechanical devices, and electronics components and can have the advantages of high integration and high-efficiency energy sources. III-V compound semiconductor cells have proven performance based on high reliability in the aerospace field, but have characteristics that require absolute support of the balance of systems (BOS) such as solar position trackers, receivers with heat sinks, and housing instruments. To determine the optimum parameters of secondary optical elements (SOEs) design for CPV systems, we designed three types of CPV modules, classified as non-SOEs type, reflective mirror type, and CPC lens type. We measured the I-V and P-V characteristics of the prototype $\mathrm{CPV}$ modules with the angle of inclination varying from $0^{\circ}$ to $12^{\circ}$ and with a 500-magnification Fresnel lens. The experimental results assumed misalignment of the solar position tracker or module design of pinpoint accuracy. As a result, at the $0^{\circ}$ tilt angle, the CPC lens produced lower power due to the quartz transmittance ratio compared to that by other SOEs. However, for tilt angles greater than $3^{\circ}$, the CPC lens type module achieved high efficiency and stability. This study is expected to help design high-performance CPV systems.
\end{abstract}

Keywords: 집광형태양전지(CPV module), 2차광학계(Secondary optical elements), 복합파라 볼릭렌즈(Compound parabolic lens), 성능분석(Performance analysis)

\section{1. 서론}

CPV (Concentration Photovoltaic)발전시스템은 기술적/환경적/경제적 측면에서의 여러 한계점을 안고 있는 기존 단결정 실리콘 PV시스템을 보완하여 사막지역 적용이나 고집적발전시스템 등에 적용될 수 있는 집적 기술에 기반한 태양광발전 시스템으로, 특히, 
높은 면적대비 발전성능을 갖춘 발전원으로 관심을 받았다. 그러나 단결정 실리콘 태양전지의 단가 하락과 더 불어 BOS (Balance of System)에 대한 의존도가 상대적으로 높은데 이는 작은 면적의 CPV 셀에 태양광을 돋보 기와 같은 광학장치를 이용하여 태양빛을 집광시켜 면적 대비 발전량을 높여가는 방식에 기반하게 되므로 인해 서 $\pm 1^{\circ}$ 이상의 높은 정밀도를 갖춘 태양위치 추적기, CPV모듈의 하우징 장치, 고집광에 따른 방열장치 등의 추 가적인 장치가 부착되어야 하는 단점을 갖는다. 이 중 태양위치 추적장치의 백래쉬와 같은 오차발생이나 추적 시스템의 정밀성을 높이기 위한 비용추가는 보완해야할 분야이며 이러한 단점을 극복하기 위한 보완기술을 구 동장치 보다는 고정장치를 이용하며 에너지손실이 없고 장기간의 내구성을 갖는 렌즈기술에서 이에 대한 솔루 션을 찾고 있으며 그에 따른 보완기술로 등장한 형태가 2차 광학계(SOEs, Secondary Optical Elements)이다. $\mathrm{CPV}$ 발전시스템은 고정밀 추적장치가 부착되어 적은 오차분으로 $\mathrm{CPV}$ 셀에 수직입사가 반드시 이루어져야 하 나 1차 렌즈의 광축과 $\mathrm{CPV}$ 셀의 정렬 불일치가 발생하는 경우를 보상하기 위한 다양한 형태의 2차 광학계가 보 완기술로 존재한다. 2차 광학계에 적용될 수 있는 CPC (Compound Parabolic Concentrator)는 1965년 Winston과 Hinterberger에 의해 고안된 광학렌즈로 일반적인 개념의 CPC는 복합형 포물선형 집광기를 의미 한다.

본 논문에서는 500배율 프레넬 렌즈를 적용한 CPV모듈을 제작하였고 여기에는 2차광학계로 적용될 수 있는 형태를 통해 CPV모듈의 최적화된 설계 자료를 확보하기 위해 3가지 형태의 모듈을 제작하여 각각의 모듈에 대 한 성능을 분석하였다. 실험을 위해 2차광학계가 없는 형태, 반사형구조를 갖는 미러형 $\mathrm{CPC}$ 구조 반사경, 그리 고 유리 재질의 $\mathrm{CPC}$ 를 적용한 형태를 각각 제작하였다. 제작된 CPV 모듈은 시뮬레이터를 이용하여 $\mathrm{I}-\mathrm{V}, \mathrm{P}-\mathrm{V}$ 특성을 측정하였다. 측정결과를 바탕으로 2차 광학계의 형태에 따른 성능분석을 통해 2차 광학계의 필요성과 설계시 반영해야 할 설계요소와 그에 따른 성능분석을 실험적으로 분석하여 집광형 태양광발전시스템 최적화 설계에 기초자료로 활용하고자 한다.

\section{2. 집광형태양광발전시스템}

\subsection{III-V 화합물 반도체 CPV Cell}

최근 세계 최고효율의 태양전지셀은 III-V 화합물반도체 3중 접합(Triple-junction)으로 미국 재생에너지연 구소(NREL)에서 개발한 143 배 집광에서 47.1\%의 효율을 나타내고 있으며 Spectrolab사에서는 240 Suns에서 최고효율 $40.7 \%$ 효율 제작하고 있다. 고효율 III-V 화합물반도체 태양전지가 이러한 높은 효율을 가질 수 있는 이유는 다중접합 탠덤 셀 구조에 있으며 가장 밴드갭이 큰 물질인 $\mathrm{GaInP}$ 를 맨 위에 적층하고 중간 밴드갭을 갖 는 물질인 $\mathrm{GaAs}$ 를 중간위치에, 그리고 가장 밴드갭이 작은 물질인 $\mathrm{Ge}$ 이 맨 아래에 위치하도록 적층한다. 따라 서 상층부의 셀에서는 밴드 갭 에너지보다 큰 부분의 태양빛의 짧은 파장영역인 가시광의 Blue계열의 스펙트럼 을 흡수하고 나서 그 다음에 중간 밴드갭을 갖는 물질이 중간 파장영역인 가시광의 Green의 스펙트럼을 흡수하 고 마지막으로 가장 긴 밴드갭 물질이 파장이 긴 스펙트럼의 영역인 Red영역을 흡수하여 태양빛의 전체 가시광 
스펙트럼에 대해서 여러 부분으로 나누어 효율적으로 흡수하여 변환하는 상대적으로 효율적인 구조를 갖는다. Fig. 1에서는 III-V 화합물반도체 태양전지의 전형적인 적층구조와 태양빛 스펙트럼구조에 따른 에너지방출량, 그리고 화합물 반도체 태양전지의 각 파장의 흡수와 에너지변환과정을 도시화 하여 나타냈다.

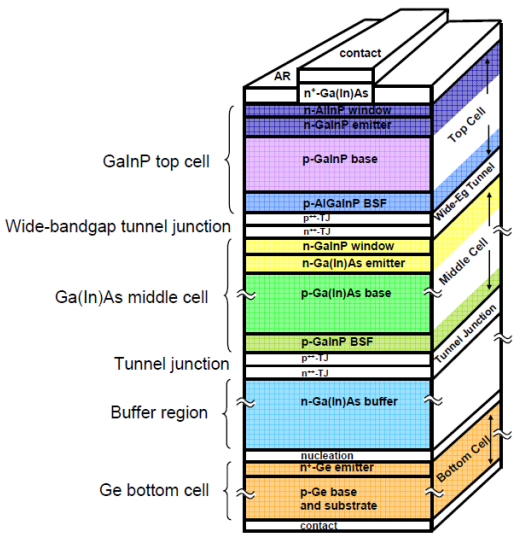

(a) Structure of CPV cell

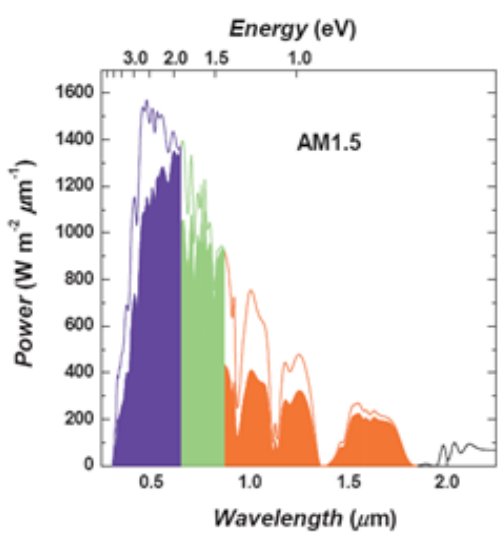

(b) Energy Spectrum

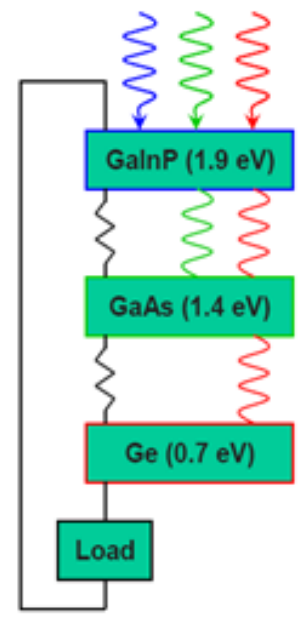

(c) Wave length sensitivity of element

Fig. 1 Schematic III-V Compound Cell and Solar energy conversion mechanism

실험에 적용된 III-V 화합물 반도체 태양전지 셀은 GaInP의 삼중접합 셀로 $(1.88 \mathrm{eV}) / \mathrm{GaInAs}(1.41 \mathrm{eV})$ / $\mathrm{Ge}(0.67 \mathrm{eV})$ 으로 $\mathrm{P}$-type 위에 N-type을 적층시키는 터널 접합설계를 통해 제작되었으며 셀의 노출면적은 6.5 $\mathrm{mm}$ X $5.5 \mathrm{~mm}$ 이고 Ge웨이퍼는 $180 \pm 20 \mu \mathrm{m}$ 두께를 가진 CPV셀이며 Fig. 2는 CPV셀의 사진을 나타낸다. 액티브 영역은 $0.3025 \mathrm{~cm}^{2}$ 이고 본딩영역의 버스바의 폭은 $0.42 \mathrm{~mm}$ 이며 전체 셀의 두께는 $0.2 \mathrm{~mm}$ 이다.

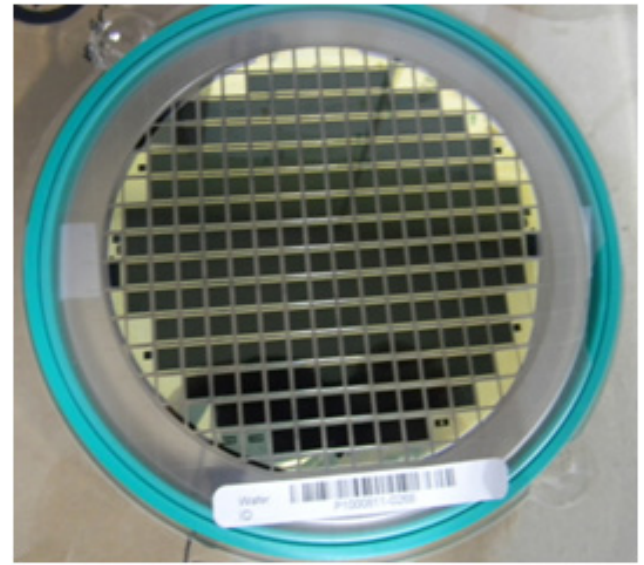

Fig. 2 Photo of III-V Compound Cell applying experiment 
Table 1에서는 본 논문의 실험에 적용된 고효율 III-V 화합물반도체 태양전지 셀의 STC (Standard Test Condition)에서 테스트를 통한 물리적, 전기적인 특성에 대해 웨이퍼 셀의 평균 사양을 나타낸다. 1SUN조건에 서 개방전압은 $3.249 \mathrm{~V}$, 단락전류는 $4.525 \mathrm{~mA}$ 이고 최대 출력전력은 $9.244 \mathrm{~mW}$ 이다.

Table 1 Cell characteristics in AM 1.5 G Spectrurm

\begin{tabular}{|c|c|c|}
\hline Specification & Value & Unit \\
\hline Unit Cell exposure area & $6.6 \times 5.6$ & $\mathrm{~mm}$ \\
\hline Active pv area & 0.3025 & $\mathrm{Cm}^{2}$ \\
\hline Total pv area & 0.368 & $\mathrm{Cm}^{2}$ \\
\hline Bondable bus bar width & 0.42 & $\mathrm{~mm}$ \\
\hline Total cell thickness & 0.2 & $\mathrm{~mm}$ \\
\hline Solar irradiation & 103.638 & $\mathrm{~mW} / \mathrm{Cm}^{2}$ \\
\hline Isc density & 20.113 & $\mathrm{~mA} / \mathrm{Cm}^{2}$ \\
\hline Isc & 4.525 & $\mathrm{~mA}$ \\
\hline Voc & 3.249 & $\mathrm{~V}$ \\
\hline Max. Power & 9.244 & $\mathrm{~mW}$ \\
\hline Fill factor & 0.629 & - \\
\hline Active area conversion efficiency & 39.641 & $\%$ \\
\hline
\end{tabular}

\subsection{III-V 화합물 반도체 CPV 시스템}

굴절형 또는 반사형 광학기구의 활용에서 CPV발전시스템은 광학배율의 측면에서 10배율 정도의 저집광과 200배율이상의 고집광시스템으로 구분 할 수 있다. 굴절형 렌즈를 적용한 CPV모듈은 발전원인 III-V 화합물 반도체 태양전지 셀, 집광을 위한 렌즈와 그리고 이 셀이 장착되어 방열구조를 확보한 리시버로 구성되며 굴절 형 렌즈는 태양빛의 집광을 위한 렌즈와 집광된 빛을 타겟 셀에 모아주기 위한 2차 광학계, SOEs로 구성되며 그 기본구조는 Fig. 3과 같다.

\subsection{CPV 모듈 등가회로 해석}

집광형 태양전지 셀의 모델은 실리콘 다이오드의 등가모델과 유사한 형태로 이루어진다. CPV셀은 전기적으 로 다이오드상수 $\left(I_{0}\right)$ 와 광전류값 $\left(I_{p h}\right)$, 그리고 직렬저항 $\left(R_{s}\right)$ 과 션트저항 $\left(R_{s h}\right)$ 등의 요소로 모델링을 할 수 있 다. 광전류값의 크기는 일사량에 비례하여 그 값을 계산할 할 수 있지만 단락운전, 개방운전 및 최대출력운전에 대한 파라미터는 제조사에서 제공하는 실험데이터에 기반하여 산출해야 한다. CPV셀을 모델링하기 위한 등가 회로는 Fig. 4와 같다. 


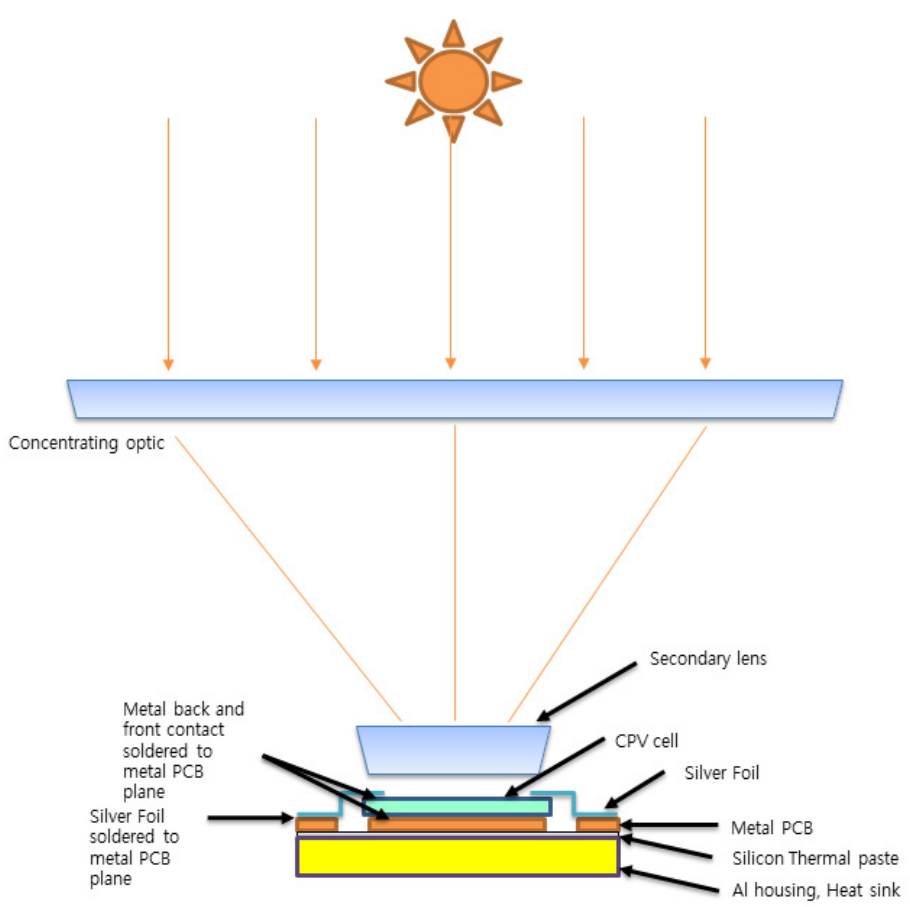

Fig. 3 Basic structure of CPV module with optical elements

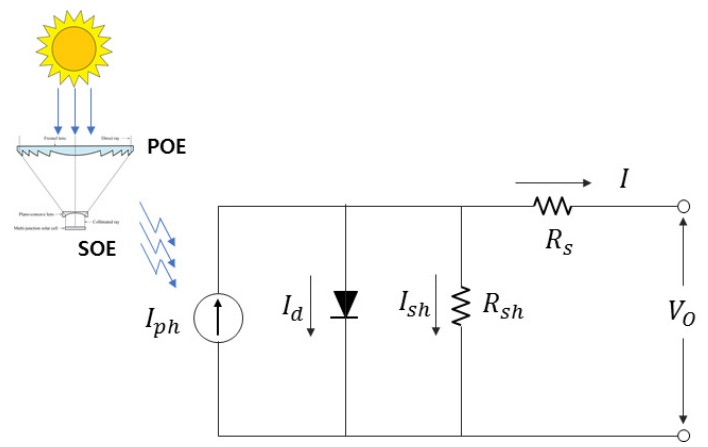

Fig. 4 CPV cell equivalent circuit

등가회로를 기반으로 한 CPV셀의 단락전류에 대한 방정식은 식(1)과 같다.

$I_{P V}=I_{p h}-I_{o}\left(e^{\frac{V_{P V}+I_{P V} R_{s}}{n_{s} v_{t}}}-1\right)-\frac{V_{P V}+I_{P V} R_{s}}{R_{s h}}$

개방전압에 대한 방정식은 식(2)과 같다.

$$
V_{O C}=\frac{k T}{q} \ln \left(\frac{I \cdot x}{1.5 \times 10^{5} \times e^{-\left(\frac{E_{q}}{k T}\right)}}+1\right)
$$


CPV모듈에서 발전된 전력은 식(3)과 같다.

$$
P_{\text {module }}=P_{c} \times a \times N_{c} \times \eta_{\text {module }}
$$

Fig. 5는 CPV모듈의 I-V, P-V 발전성능을 분석한 특성그래프이다. I-V특성곡선은 최대출력점을 산출하는 데 사용되는 중요한 특성분석을 나타내며 $\mathrm{P}-\mathrm{V}$ 곡선은 최대 전력의 생산량을 나타냄으로서 셀의 발전량을 관찰 할 수 있다. 여기에서 $I_{S C}$ 는 단락전류, $V_{O C}$ 는 개방회로, $I_{m p}$ 는 최대출력점에서의 전류값, $V_{m p}$ 는 최대출력점 에서의 전압값을 각각 의미한다.

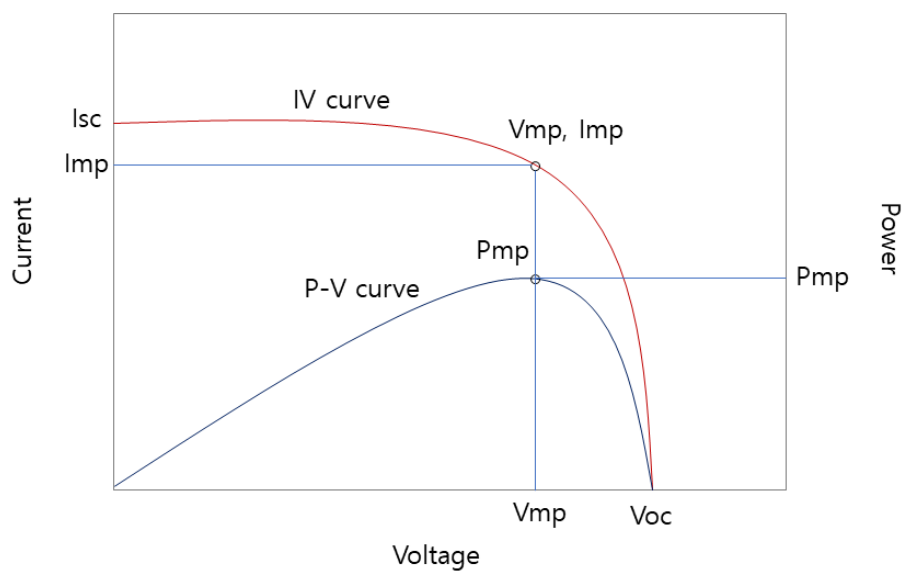

Fig. 5 P-I-V characteristics curves of CPV cell

\section{3. 실험을 위한 CPV 모듈 설계}

\subsection{SOEs의 설계}

2차 광학계로 적용된 $\mathrm{CPC}$ 는 포물선형태의 반사판이 조리개부터 흡수판까지 광선을 깔대기 형태로 구성된 다. 내부반사형 포물면 렌즈는 여러 방향에서 입사하는 빛을 유선형의 측면에서 반사시키는 것으로 출사단면에 빛을 모을 수 있는 광학소자이다. 성능분석을 위해 CPC 2차 광학계가 적용된 CPV모듈을 제작하여 비교성능시 험을 수행하였으며 실험은 $1,000\left[\mathrm{~W} / \mathrm{mm}^{2}\right]$ 의 STC조건에서 실험을 수행하여 일사강도에 따른 특성분석을 수 행하였다. CPC렌즈 비구면 공식은 식(4)과 같다.

$$
Z(x)=1+\frac{C x^{2}}{\sqrt{1-(1+K) C^{2} x^{2}}}+a^{2} x^{2}+a^{4} x^{4}+a^{6} x^{6}+a^{8} x^{8}+a^{12} x^{12}
$$


Table 2는 실험에 적용된 CPC 세컨더리 렌즈의 렌즈 비구면 공식의 상수값을 나타낸다.

Table 2 CPC SOEs constant values

\begin{tabular}{cc}
\hline Coefficient & Numerical value \\
\hline $\mathrm{C}$ & -0.00661615 \\
$\mathrm{~K}$ & 21.98945555 \\
$a^{2}$ & $6.634803136 \times 10^{-4}$ \\
$a^{4}$ & $-3.044342187 \times 10^{-6}$ \\
$a^{6}$ & $6.004115152 \times 10^{-9}$ \\
$a^{8}$ & $-1.208582175 \times 10^{-11}$ \\
$a^{10}$ & $1.189971496 \times 10^{-14}$ \\
$a^{12}$ & $-5.290757204 \times 10^{-18}$ \\
\hline
\end{tabular}

실험에 따른 $\mathrm{CPC}$ 세컨더리 렌즈의 외경과 형태는 Fig. 6과 같다.

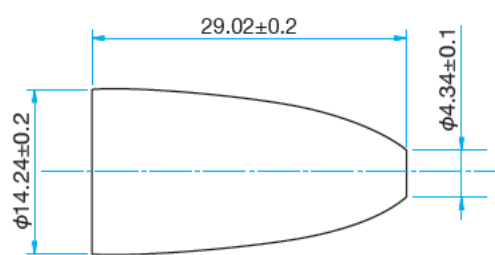

(a) CPC outlet

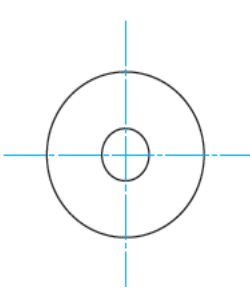

Fig. 6 CPC SOEs outlet and photo

$\mathrm{CPC}$ 재료는 $\mathrm{B} 270$ 이고 허용 입사각은 $25^{\circ}$ 이며 측면의 반사율은 $95 \%$ 이상이다. $\mathrm{CPC}$ 반사경은 대형모듈에서 적용이 용이하나 소형모듈에서는 제작단가 등을 고려하여 CPC 형상과 동일한 구조로 설계 제작하였다. 2차광 학계의 설계 중 반사경은 알루미늄 소재를 이용하여 가공하였고 크롬 고반사코팅을 통해서 반사면의 산화를 방 지하고 반사율을 높이는 후처리를 수행하여 반사율은 85\% 수준이다.

\subsection{CPV 모듈 프로토타입 제작}

실험을 위한 CPV모듈의 리시버는 고집광에 따른 CPV셀에 발생하는 열을 흡수, 분산하기 위해 메탈 $\mathrm{PCB}$ 를 활용하여 설계 적용하였다. 주변온도 $40^{\circ} \mathrm{C}$ 에서 $60^{\circ} \mathrm{C}$ 이하 접촉면 온도유지를 위한 메탈PCB 설계는 알루미늄 베이스 $2.0 \mathrm{~mm}$, 동박 두께 $70 \mu \mathrm{m}$, 절연층 두께 $100 \mathrm{~mm}$ 를 갖는 메탈 $\mathrm{PCB}$ 를 설계 적용하였고, 실리콘 써멀그 리스를 방열판과의 접촉을 일체화하기 위하여 $\mathrm{PCB}$ 와 함체 사이에 적용하였다. 실리콘 써멀그리스의 성능은 열 전달계수 $\mathrm{k}=1.2 \mathrm{~W} / \mathrm{mK}$ 이다. Fig. 7 (a)는 CPV모듈의 회로도를 나타낸다. 실험을 위한 CPV모듈은 1 개의 
$\mathrm{CPV}$ 셀에 한 개의 바이패스 다이오드가 부착되어 셀 파손 시 발생할 수 있는 직렬연결 시의 개방상태를 보정하 도록 하였다. 또한, 직렬연결된 블로킹 다이오드를 통해 이웃한 어레이에서 발생한 역전압의 유입을 차단하는 역할을 하도록 회로를 구성하였다. Fig. 7 (b)는 CPV의 PCB를 위한 아트웍을 나타내며 방열을 고려하여 설계 반영하였다.

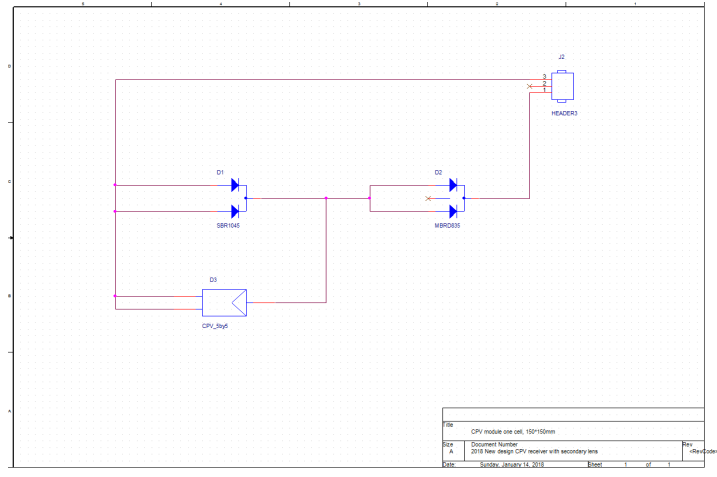

(a) Circuit design with CPV cell

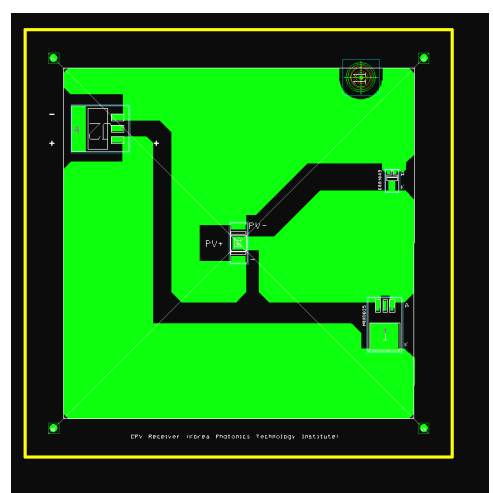

(b) CPV receive artwork

Fig. 7 Circuit and artwork design of CPV cell

\section{3. 성능비교실험을 위한 CPV시스템 구성}

굴절형 CPV모듈을 구성하여 2차 광학계를 각각 다른 조건으로 반영하여 2차 광학계가 모듈의 성능에 미치는 영향에 대한 실험을 실시하기 위해서 3가지의 비교 성능을 분석하기 위해 CASE1은 2차 광학계를 사용하지 않는 경우, CASE2는 CPC의 곡률을 이용한 반사형 렌즈를 사용한 경우, CASE3는 CPC렌즈를 적용한 경우를 각각 제 작하여 비교실험을 실시하였다. Fig. 8은 실험을 위하여 세 가지 경우로 구분하여 제작된 CPV모듈을 나타낸다.

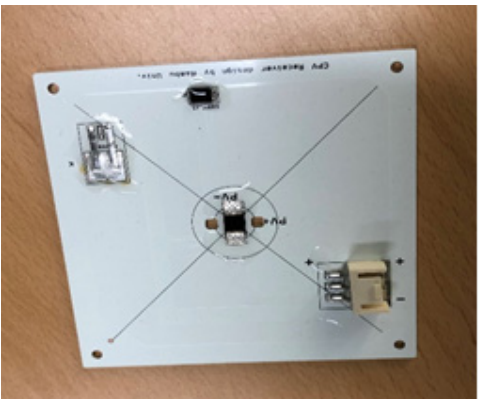

(a) Case 1: Non SOEs type

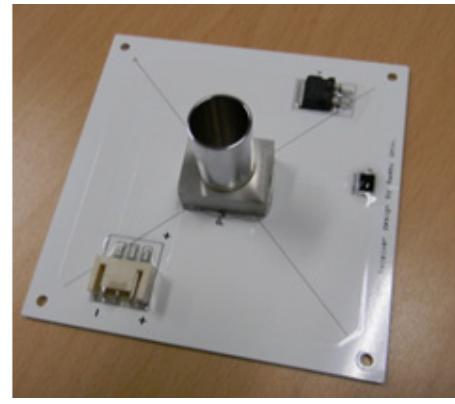

(b) Case 2: Reflective mirror type

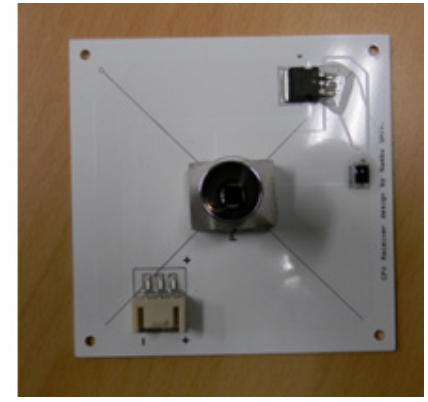

(c) Case 3: CPC lens type

Fig. 8 CPV module prototype for experiment

실험은 CPV모듈의경사각도를 3 단위로 가변하면서 CPV모듈의 발전성능을 분석을 수행하여 성능을 비교 분석하였다. Fig. 9는 Tilt각도를 가변하면서 각 모듈의 성능을 분석하는 형상을 나타내고 있다. 


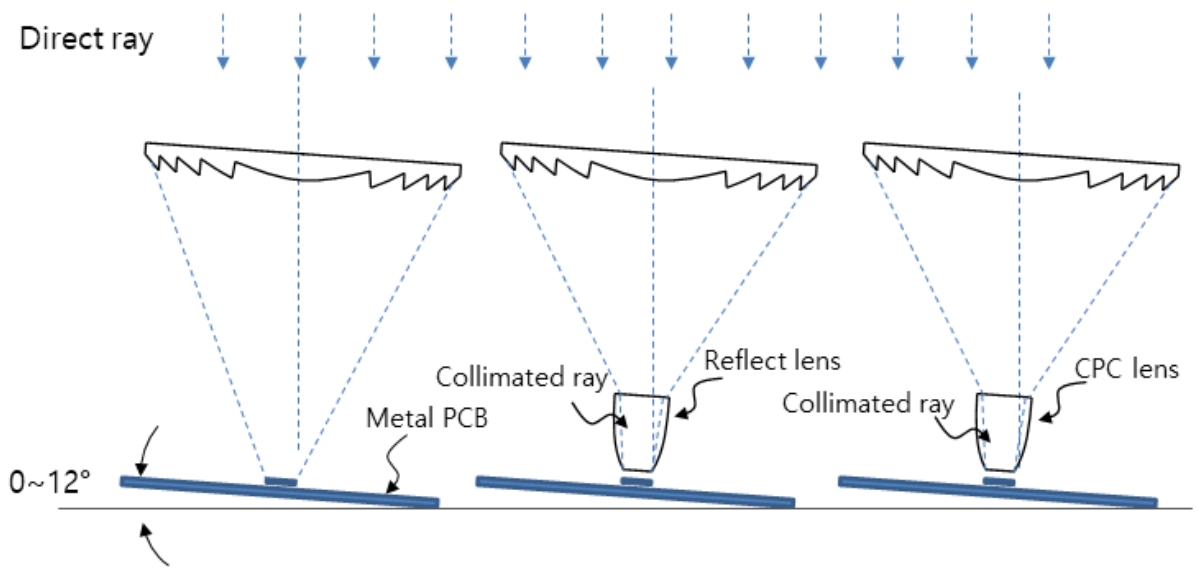

(a) Case 1: Non SOEs type (b) Case 2: Reflective mirror type (c) Case 3: CPC lens type

Fig. 9 Tilt angle variation from $0^{\circ}$ to $12^{\circ}$

\section{4. 실험결과}

Fig. 10은 CASE1으로 렌즈도 없고 반사경도 없는 CPV모듈에 500배율 집광으로 경사각도를 $0^{\circ}, 3^{\circ}, 6^{\circ}, 9^{\circ}$ 로 변화시켜가면서 I-V 특성을 비교분석한 데이터이며 Fig. 11은 CASE1에 대한 P-V 특성 실험결과를 비교한 그 래프이다.

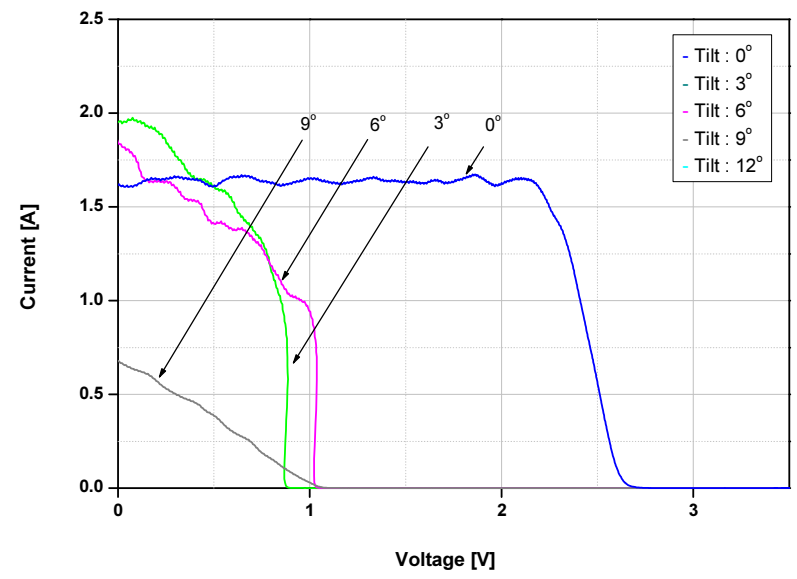

Fig. 10 CASE1, 500X, tilt $=0^{\circ}, 3^{\circ}, 6^{\circ}, 9^{\circ} \mathrm{I}-\mathrm{V}$ characteristics

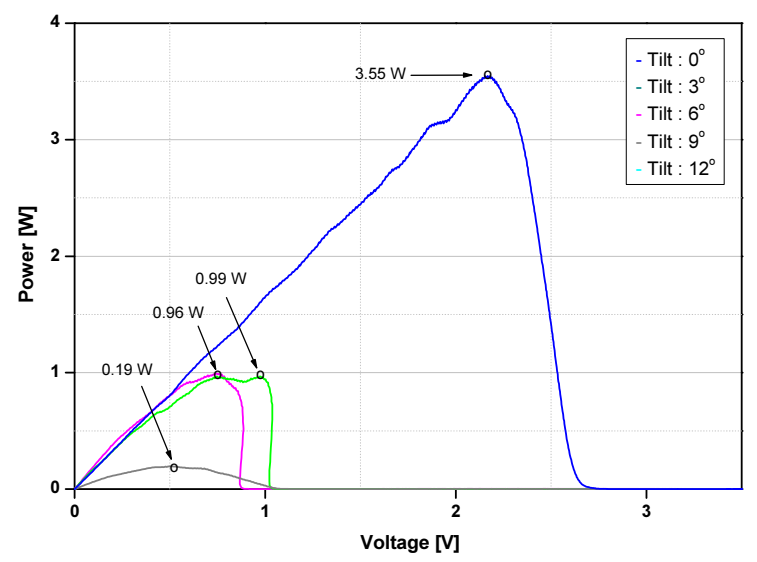

Fig. 11 CASE $1,500 X$, tilt $=0^{\circ}, 3^{\circ}, 6^{\circ}, 9^{\circ} \mathrm{P}-\mathrm{V}$ characteristics

Fig. 12는 CASE2이며 반사경을 적용한 500배율 집광으로 경사각도를 $0^{\circ}, 3^{\circ}, 6^{\circ} 9^{\circ}$ 변화시켜가면서 I-V 특 성을 비교분석한 그래프이며 Fig. 13은 CASE2 P-V 특성에 대한 실험결과를 비교한 그래프이다. 


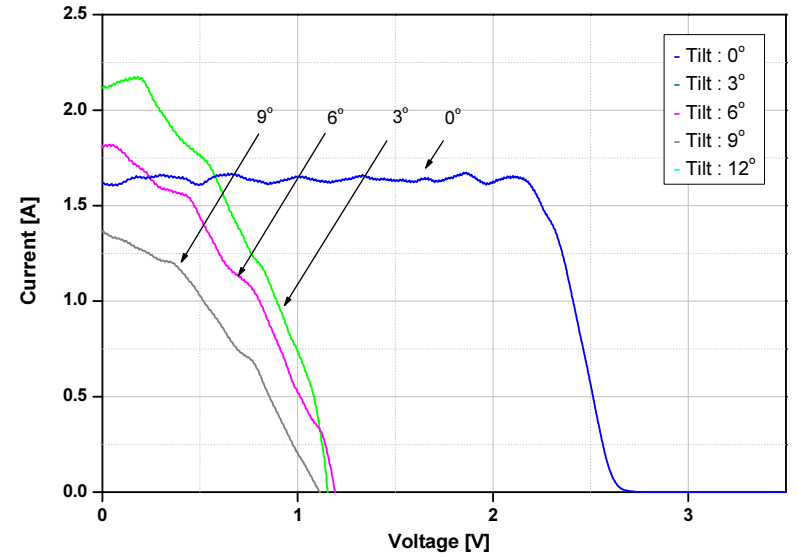

Fig. 12 CASE2, 500X, tilt $=0^{\circ}, 3^{\circ}, 6^{\circ}, 9^{\circ} \mathrm{I}-\mathrm{V}$ characteristics

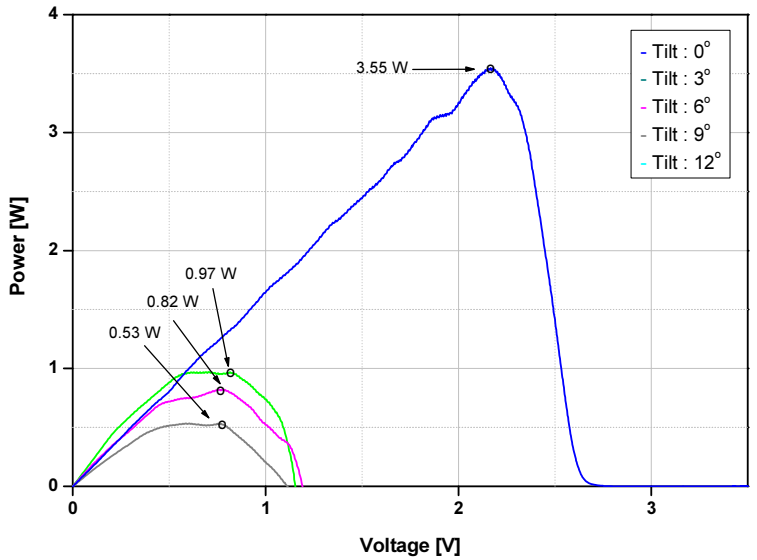

Fig. 13 CASE2, 500X, tilt $=0^{\circ}, 3^{\circ}, 6^{\circ}, 9^{\circ} \mathrm{P}-\mathrm{V}$ characteristics

Fig. 14는 CASE3으로 CPC를 적용한 500배율 집광으로 경사각도를 $0^{\circ}, 3^{\circ}, 6^{\circ} 9^{\circ}$ 를 변화시켜가면서 I-V 특 성을 비교분석한 그래프이며 Fig. 15는 CASE3의 P-V 특성에 대한 실험결과를 비교한 그래프이다.

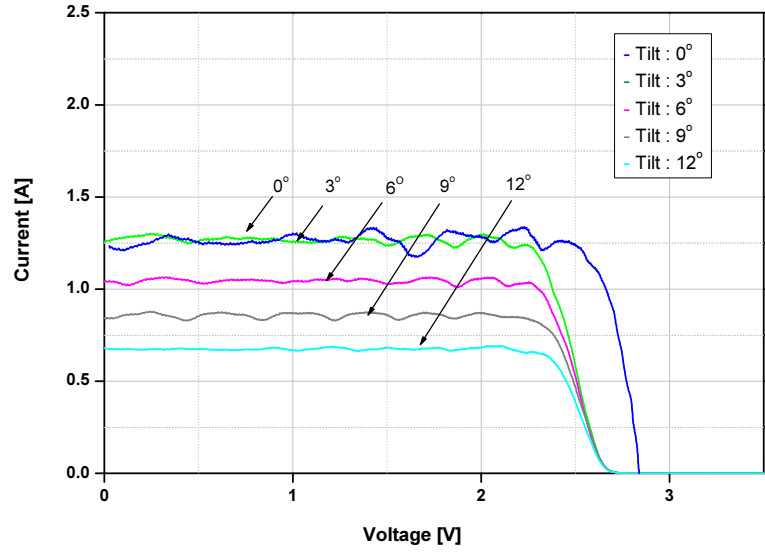

Fig. 14 CASE3, 500X, tilt $=0^{\circ}, 3^{\circ}, 6^{\circ}, 9^{\circ} \mathrm{I}-\mathrm{V}$ characteristics

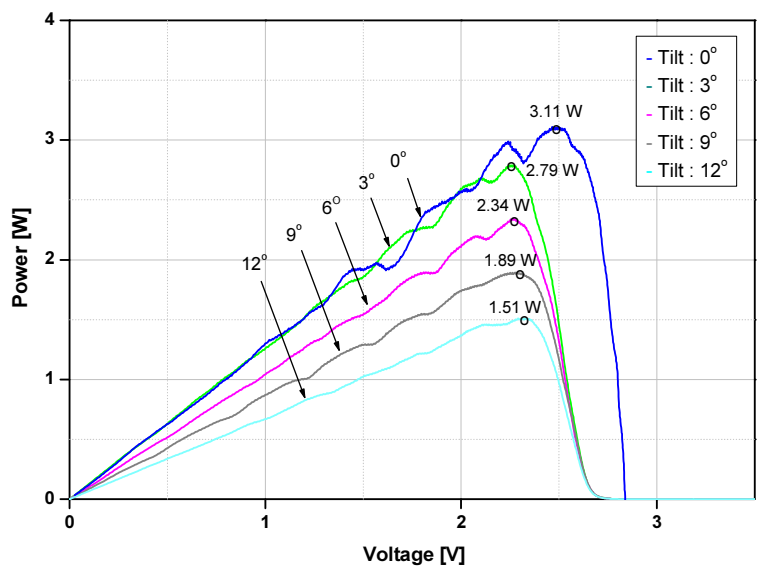

Fig. 15 CASE3, 500X, tilt $=0^{\circ}, 3^{\circ}, 6^{\circ}, 9^{\circ} \mathrm{P}-\mathrm{V}$ characteristics

Table 3은 2차 광학계의 형태에 따른 CPV모듈 실험결과를 정리하여 나타냈다. 경사각이 0인 경우에는 CPC 렌즈의 투과손실만큼의 손실이 발생하였음을 확인할 수 있다. CPC의 투과율은 95\%이상으로 나타났지만 표면 오염 등의 요인으로 $10 \%$ 내외의 투과손실이 발생한 것으로 분석된다.

Table 3 Test results for power generation values for each CASE

\begin{tabular}{ccccc}
\hline & Tilt $=0^{\circ}$ & Tilt $=3^{\circ}$ & Tilt $=6^{\circ}$ & ${\text { Tilt }=9^{\circ}}^{\circ}$ \\
\hline CASE1 & 3.55 & 0.99 & 0.96 & 0.19 \\
CASE2 & 3.55 & 0.97 & 0.92 & 0.53 \\
CASE3 & 3.11 & 2.79 & 2.34 & 1.89 \\
\hline
\end{tabular}


모듈의 경사가 $3^{\circ}$ 이상의 발생 시에는 $\mathrm{CPC}$ 렌즈를 사용한 경우가 그렇지 않은 경우보다 상대적으로 안정적으 로 보상해주는 것을 관찰 할 수 있다. 이러한 비교분석은 Fig. 16을 통해서 각 CASE에 대한 실험결과에 대한 그 래프를 통해서 확인할 수 있다.

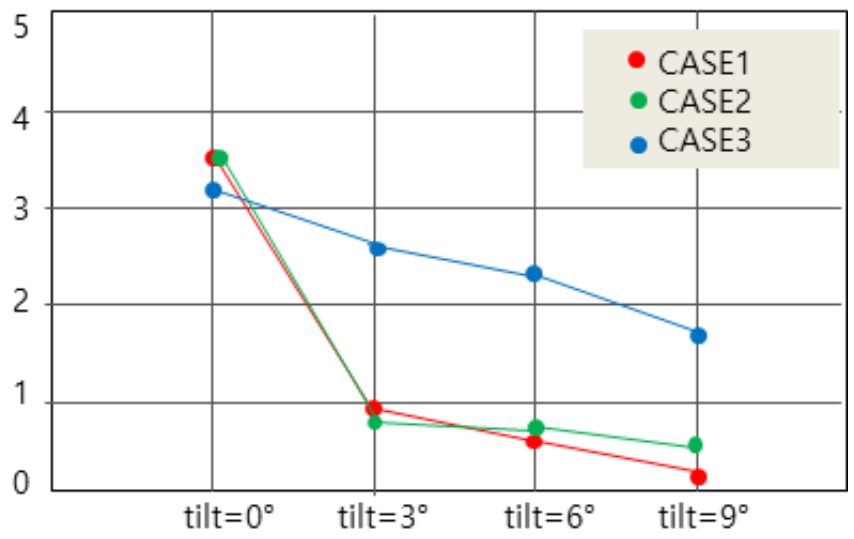

Fig. 16 Comparition graph of test results for power generation values for each CASE

\section{5. 결론}

고배율 프레넬 렌즈를 적용한 CPV 모듈을 설계 제작하는데 있어 2차 광학계의 적용은 고집광에 따른 초점 형 성 오류나 추적기의 성능보상의 역할 등 매주 중요한 설계 파라미터로 중요한 역할을 한다. 실험을 위해 최적화 된 CPV모듈을 설계하여 실험의 신뢰성을 높이기 위해서 셀 단위로 모듈을 제작하여 500배율로 제작된 시뮬레 이터를 통해 I-V특성, $\mathrm{P}-\mathrm{V}$ 특성을 측정하였다. 실험결과, 각각 다른 2차 광학계를 이용하여 태양광의 수직입사 가 추적기나 모듈의 비정렬로 인한 오차발생 시에 대한 실험을 수행한 결과 $\mathrm{CPC}$ 를 적용한 경우가 2차 광학계를 채택하지 않는 경우나 반사형을 사용한 경우보다 초기 투과율로 인해 낮은 발전량을 나타냈으나 오차가 커짐에 따라 매우 높은 안정성을 나타냈다. 또한 $\mathrm{CPC}$ 반사경은 소형 모듈의 경우에 반사경면의 성능을 유지하는데 어려 움이 크고 그로 인해 $\mathrm{CPC}$ 렌즈보다 낮은 성능결과를 나타냄으로서 소형모듈에서 반사경에 대한 적용은 추가적 인 실험을 통해 성능확보를 위한 설계와 소재의 선택이 필요하다. 제안된 실험의 결과를 토대로 향후 CPV모듈의 설계 시에 2차 광학계의 설계 파라미터로 활용하여 최적설계를 위한 데이터의 기반이 될 것으로 기대된다.

\section{후기}

이 논문은 2019년도 남부대학교 학술연구비의 지원을 받아 연구되었음. 


\section{REFERENCES}

1. Jeong, B. H., Lee, K. Y., Park, J. H., Moon, E. A., and Lee, S. H., A Characteristics of the Applied SOG Lens for the CPV Module, The Transactions of The Korean Institute of Electrical Engineers P, Vol. 61, No. 02, pp. 97-102, 2012.

2. Lee, K. Y., Jeong, B. H., and Kim, H. J., Applied Spherical Lens with Reflect Mirror for the CPV module, Journal of the Korean Institute of Illuminating and Electrical Installation Engineers, Vol. 25, No. 11, pp. 83-90, 2011.

3. Lee, K. Y., Jeong, B. H., and Kim, J. W., Using the Loss Parameter Calculation Method for the CPV System Simulation, Journal of The Korea Convergence Society, pp. 18-26. 2017.

4. Jeong, W. L., Kim, K. P., Min, J. H., and Lee, J. Y., Optimization of the Secondary Optical Element of a Hybrid Concentrator Photovoltaic Module Considering the Effective Absorption Wavelength Range, Appl. Sci. 2020, Vol. 10, p. 2051, 2020.

5. Fontani, D., Sansoni, P., Francini, F., DeLucia, M., Pierucci, G., and Jafrancesco, D., Optical Tests on a Curve Fresnel Lens as Secondary Optics for Solar Troughs, Int. J. Photoenergy 2017, pp. 1-11, 2017.

6. Nardello, M. and Centro, S., Developing Instrumentation for Analysis of CPV TwinFocus ${ }^{\circledR}$ System, Journal of Physics: Conf. 2019, pp. 1-6, 2019.

7. Bett1, A.W., Burger, B., Dimroth, F., Siefer, G., and Lerchenmuller, H., High-Concentration PV using III-V Solar Cells, Presented at 7. the 2006 IEEE 4th World Conference on Photovoltaic Energy Conversion, pp. 7-12, 2006.

8. Chen, Y. C. and Chiang, H. W., Design of the Secondary Optical Elements for Concentrated 8. Photovoltaic Units with Fresnel Lenses, Appl. Sci. 5, pp. 770-786, 2015.

9. Salmi, T., Bouzguenda, M., Gastli, A., and Masmoudi, A., MATLAB/Simulink Based Modeling of Solar 9. Photovoltaic Cell, International Journal of Renewable Energy Research, Vol. 2, No. 2, pp. 214-218. 2012.

10. Siaw, F. L. and Chong, K. K., A Systematic Method of Interconnection Optimization for Dense-Array Concentrator Photovoltaic System, The Scientific World Journal, Article ID 275169, Vol. 2013. pp. 1-11, 2013.

11. Park, S. M. and Kim, J. B., Experimental Study on Performance Evaluation of the Reflector Designed for CPV Solar System., Korea Solar Energy Society, Vol. 36, No. 2, 2016.

12. Kang, S. W., Kim, Y. S., and Sim, C. H., PV Receiver Raytracing Simulation with Secondary Optics in the CPV (Concentrated PV) System., Korea Solar Energy Society, Vol. 30, No. 2, pp. 323-331. 2010. 